\title{
Mediastinal huge non-Hodgkin's lymphoma causing compression of the main pulmonary artery trunk
}

\author{
Reiko Mizuno, Shinichi Fujimoto, Yasuyuki Okamoto
}

Nara Medical University, Kashihara, Nara, Japan

Correspondence to Dr Reiko Mizuno,rmizuno@naramed-u.ac.jp

\section{DESCRIPTION}

A 24-year-old man presented with dyspnoea on exertion. Chest x-ray showed an enlargement of the upper anterior mediastinum (figure 1A). Chest CT showed a huge mass with the size of $7.6 \times 4.8 \mathrm{~cm}$ in the upper anterior mediastinum (figure $1 \mathrm{~B}$ ). This mass compressed the main pulmonary artery trunk (MPA) and the left pulmonary artery. Transthoracic two-dimensional echocardiography also revealed a huge mass compressing the MPA extrinsically (figure 2A). Continuous-wave Doppler echocardiography demonstrated a peak systolic pressure gradient of $15.6 \mathrm{~mm} \mathrm{Hg}$ at the site of the MPA compression (figure 2B). By transthoracic CT-guided needle biopsy he was diagnosed as primary mediastinal large B-cell non-
Hodgkin's lymphoma (figure 1C). He was treated with the standard CHOP (cyclophosphamide, doxorubicin, vincristine and predonine). On the post-treatment chest CT (figure 1D), mediastinal lymphoma was reduced and the MPA compression was not seen. On the post-treatment echocardiography (figure 2C), the MPA compression and the significant pressure gradient in the MPA was not detected. Dyspnoea on exertion disappeared with disappearance of the significant pressure gradient. Acquired pulmonary artery stenosis is rarely found in adults. The mediastinal tumour can cause extrinsic compression of the pulmonary artery. Marshall et a ${ }^{1}$ reported that teratoma and Hodgkin's lymphoma were most frequent. Primary mediastinal large B-cell non-Hodgkin's lymphoma
A

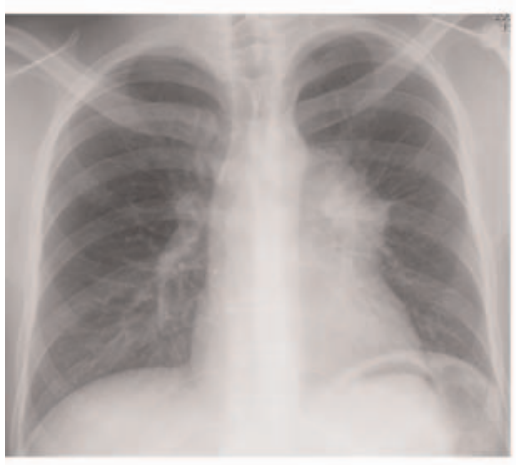

C

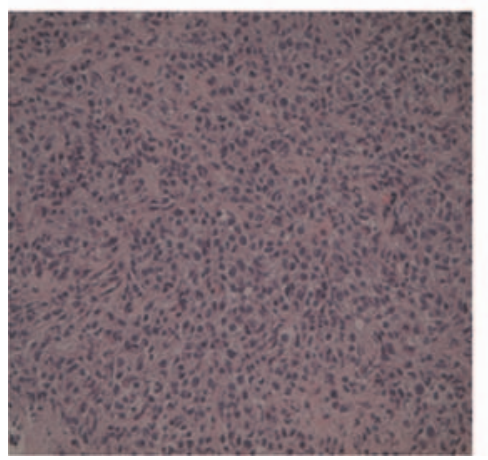

B

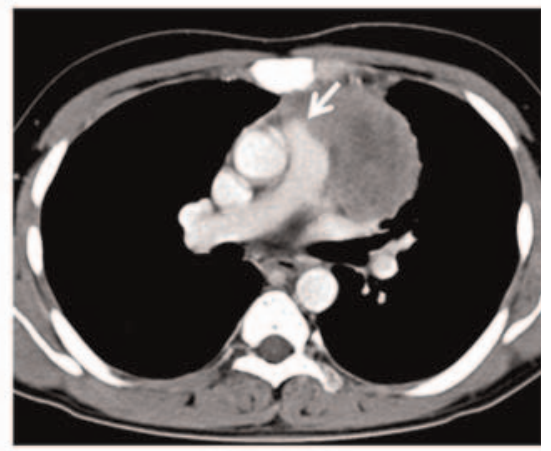

D

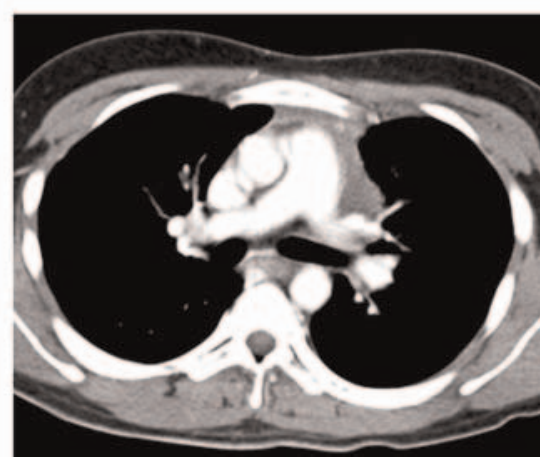

Figure 1 (A) Pretreatment chest $x$-ray showed an enlargement of the upper anterior mediastinum. (B) Pretreatment chest CT demonstrated a huge mass in the upper anterior mediastinum compressing the main pulmonary artery (MPA) and left pulmonary artery. White arrow indicates the compression of the MPA. (C) On post-treatment CT the mediastinal mass was reduced and the compression of the MPA was not detected. (D) Histological analysis of transthoracic CT-guided needle biopsy from the mediastinal mass showed primary mediastinal large B-cell non-Hodgkin's lymphoma. 


\section{BMJ Case Reports}

A

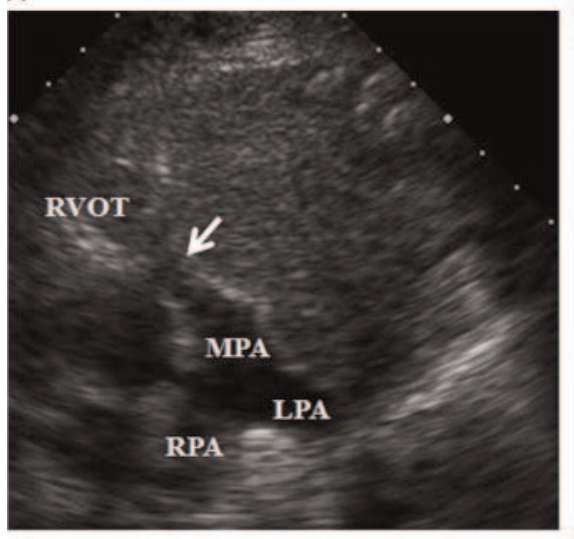

B

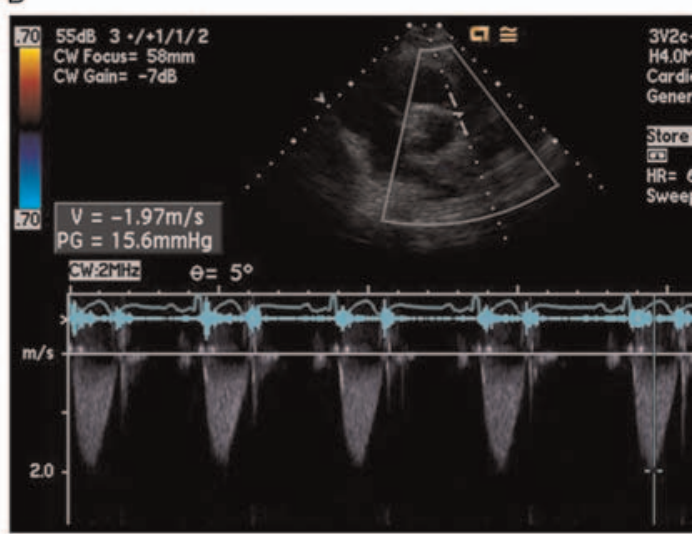

C

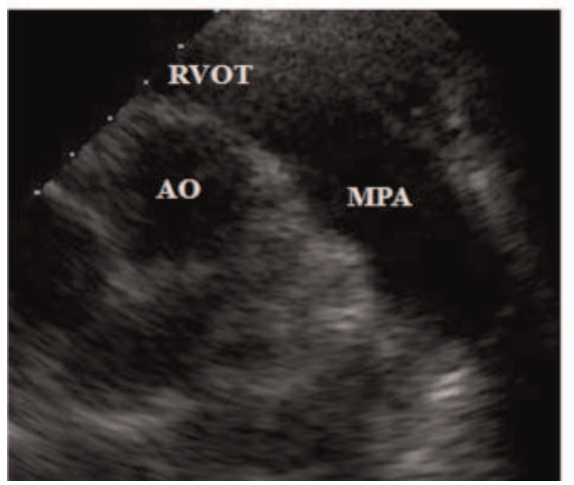

Figure 2 (A) Pretreatment transthoracic two-dimensional echocardiography showed a huge mediastinal mass compressing the main pulmonary artery (MPA) extrinsically. (B) Continuous-wave Doppler echocardiography demonstrated a peak systolic pressure gradient of $15.6 \mathrm{~mm} \mathrm{Hg}$ at the site of the MPA compression. (C) Post-treatment echocardiography showed disappearance of the MPA compression. A0, aorta; LPA, left pulmonary artery; RVOT, right ventricular outflow tract. Other abbreviation as in figure 1.

is a rare subtype of large B-cell non-Hodgkin's lymphoma. This rare type is reported to have involvements of the surrounding vessels in one-third of patients. ${ }^{2}$ Robinson et al $l^{3}$ previously reported the case with compression of the right pulmonary artery by mediastinal non-Hodgkin's lymphoma. Meanwhile, the MPA has a large lumen that does not easily cause a stenosis with impeding blood flow. Therefore, it is very rare that the MPA involvement impedes blood flow with significant haemodynamic impairment as seen in the present case.

\section{Competing interests None.}

Patient consent Obtained.

\section{REFERENCES}

1. Marshall ME, Trump DL. Acquired extrinsic pulmonic stenosis caused by mediastinal tumors. Cancer 1982:49:1496-9.

2. Popat U, Przepiork D, Champlin R, et al. High-dose chemotherapy for relapsed and refractory diffuse large B-cell lymphoma: mediastinal localization predicts for a favorable outcome. J Clin Oncol 1998;16:63-9.

3. Robinson T, Lynch J, Grech E. Non-Hodgkin's lymphoma causing extrinsic pulmonary artery compression. Eur J Echocardiogr 2008:9:577-8.

This pdf has been created automatically from the final edited text and images.

Copyright 2012 BMJ Publishing Group. All rights reserved. For permission to reuse any of this content visit http://group.bmj.com/group/rights-licensing/permissions.

BMJ Case Report Fellows may re-use this article for personal use and teaching without any further permission.

Please cite this article as follows (you will need to access the article online to obtain the date of publication).

Mizuno R, Fujimoto S, Okamoto Y. Mediastinal huge non-Hodgkin's lymphoma causing compression of the main pulmonary artery trunk. BMJ Case Reports 2012;10.1136/bcr-2012-006530, Published XXX

Become a Fellow of BMJ Case Reports today and you can:

- Submit as many cases as you like

- Enjoy fast sympathetic peer review and rapid publication of accepted articles

- Access all the published articles

- Re-use any of the published material for personal use and teaching without further permission

For information on Institutional Fellowships contact consortiasales@bmjgroup.com

Visit casereports.bmj.com for more articles like this and to become a Fellow 